\title{
The Urgencies of Collaborative Governance in Strengthening Non-Military Defense
}

\author{
Irwan Firdaus ${ }^{1 *}$ I Wayan Midhio ${ }^{1 *}$ Muhammad Nakir ${ }^{1 *}$ \\ 1. Faculty of Defense Strategy, Indonesia Defense University, Indonesia Peace and Security Center - \\ Bogor, Indonesia \\ * E-mail of the corresponding author: irwan.f3993@gmail.com
}

\begin{abstract}
The threat to national security nowadays is not limited to the military domain but has targetted the multi-dimension and multi-actor non-military domain. War definition then shifted from the dominance of the physical battles among military powers variable to non-physical battles among ideologies, politics, economics, and socio-cultural variable. This characteristic of confrontation seems more intensified in the future. Addressing the realities, Indonesia has formulated a formal-legal foundation for non-military defense as a part of the national defense strategy. To implement it well at a practical level, the complexity of non-military defense must meet with collaborative governance. This paper will discuss the urgency of the collaborative governance method in order to strengthen Indonesia's non-military defense. The objective of building a non-military defense is to organize a strong collaboration of governmental institutions for creating a total defense system mainly to encounter non-military threats. Well-integrated collaborative governance is one of the determinant factors on the success of the nonmilitary defense.
\end{abstract}

Keywords: collaborative governance, non-military defense, non-military threat, strategy

DOI: $10.7176 / \mathrm{IAGS} / 86-05$

Publication date:September $30^{\text {th }} 2020$

\section{Introduction}

The strategic environment for global and regional security in recent years has become increasingly complex, erratic, and volatile. Predictions of future threats today have to deal with the difficulty of identifying regularities in various phenomena as asymmetric approaches increasingly dominate the global political constellation. At the regional level, for example, the geopolitical rivalry between the holders of the status quo hegemon, the United States, and the new challenger, China, has led to the intensification of the Indo-Pacific program in the Southeast Asia region. Indonesia with the Association of Southeast Asian Nations (ASEAN) vehicle then tries to convert this reality into opportunities for cooperation with an orientation to non-military issues (Oktaviano, Mahroza, and Risman, 2020).

At the domestic level, Indonesia still has to grapple with the effort to improve and increase the capacity of the budget, institutions, and human resources for defense as well as civil and military relations. The Coronavirus Disease-2019 (COVID-19) pandemic, which is still spreading to date, has forced a reduction of 8.7 trillion from the defense budget of 131.2 trillion, which is already relatively small (less than $1 \%$ of GDP) (Kompas.com, 2020). On the other hand, civilian mobilization for national defense affairs is still difficult to implement even with a persuasive approach due to the trauma of the New Order as reflected in the public reaction to the passing of the National Resource Management Law for National Defence (PSDN) in 2019.

The development of such a strategic environment towards security has positioned a non-military threat which has strategic implication as a military threat. Barry Buzan (1998), although he does not explicitly categorize threats based on military and non-military threats, from the conception of the security sectors, non-military threats can be formulated consisting of economic threats, political threats, social threats, and environmental threats (Buzan and Wilde, 1998, p.7). Categorization and interpretation of these types of threats certainly have an impact on how the institutions and mechanisms that will be applied by a political entity can work together.

Indonesia has provided a formal-legal foundation in national defense efforts, both military and non-military, as stipulated in Act No. 3/2002 concerning National Defense. Several derivative rules have been attempted to be derived to follow up on the widening and deepening of threats in this contemporary era. To harmonize defense efforts and strengthen their realization at the technical level, there are still some urgencies that have not been implemented effectively, namely building collaboration across government and community components in order to achieve universal defense as mandated in the Minister of Defense Regulation (Permenhan) No. 26/2014. 
Collaborative governance is the idealism of public administration which is popular today in both the academic and practical realms. Synergy across roles and actors in management is deemed important to accommodate threats, challenges, obstacles, and disturbances as well as their developments that cannot be easily estimated. Thus, thought and initiative emerged to implement this collaborative governance in defense efforts which are considered to be highly dependent on active multi-stakeholder involvement and synergy, namely non-military defense.

This paper discusses the urgency of implementing collaborative governance in strengthening non-military defense in Indonesia. This paper is expected to provide theoretical benefits as a reference on non-military defense, collaborative governance, and case studies on these two concepts. At the executive and policy level, this paper is expected to be an important input for the strategic plan and implementation framework for strengthening nonmilitary defense. The discussion of this topic in the next chapter is discussed in two parts, non-military defense and the urgency of collaborative governance

\section{Literature Review}

This paper presents two main theoretical frameworks: the theory of collaborative government and the concept of non-military defense. Collaborative government theory is a very broad concept in the sense that there is no specific feature of a particular political entity. Meanwhile, the concept of non-military might draw many similarities from several alternative meanings, but when juxtaposed with the defense features, the idealism of non-military defense is relatively unique between countries. Therefore, the description of non-military defense in this paper will prioritize the definitions contained in the laws and publications of the government of the Republic of Indonesia.

Collaborative refers to a trait characterized by a combination of energy to achieve common goals in work that is cross-border and cross-sectoral (Wargadinata, 2017). Collaborative governance is defined as a collective decisionmaking method in which public agencies and non-state stakeholders are linked to one another in a consensus-based negotiation process to find and implement public policies and procedures for managing public resources (Johnston et al. 2011, 699). This idea emerged along with the increasingly complex problems faced by one formal political institution entity at a time when the bureaucratic conservative order was increasingly unpopular (O'Leary, 2008).

A number of reasons explain why this collaborative style of government is necessary. First, public problems are increasingly complex and difficult to be handled by a single government organization, therefore it requires many approaches. Second, the outsourcing mechanism that the government has begun to implement for institutional effectiveness depends on collaboration with parties outside the government. Third, the demands for the effectiveness of the wheels of government and the great penetration of technological features in people's lives force innovation and new approaches in public services. Fourth, there is a greater demand from the community to be involved in the process of formulating government policies (Wargadinata, 2017).

Collaborative governance is supported by collaborative leadership as well. Among the elementary features of collaborative leadership are: (1) understanding the power possessed by all parties involved; (2) does not monopolize information related to the issue to be decided; (3) facilitate and encourage each party to participate in voicing their opinions and provide opportunities for all to take responsibility for the decisions that have been taken; (4) devote time and resources to the benefit of all parties involved, including providing feedback on their contributions; and (5) do not act passively waiting for reports on the resolution of a problem, but rather take part in finding solutions to the root causes (Wargadinata, 2017).

The expected outcome of collaborative governance is a "collaborative advantage", that is, the achievement of a policy or coordination product that cannot be implemented by a single organization. There is much more satisfaction that can be given to the parties involved. This is because collaborative governments uphold consensus, the principle of mutual respect between parties, and prioritize negotiations in dealing with differences.

To realize a collaborative government, many stages must be passed. The first is to carry out a study, which aims to answer whether this collaboration is needed, whether the preconditions have been met, who are the stakeholders, and who will be in a strategic position. The second stage is initiation, which explains how the issues will be framed, how to engage stakeholders, what process will be followed, and identifying what / who else is needed. The third stage is negotiation, which aims to solidify answers on the development of effective working groups, regulations, mechanisms for finding options and policies, and ways to facilitate shared learning. Finally, the implementation stage is to formulate the main tasks and functions of each party, raise support, develop a governance structure, and monitor progress (Morse \& Stephens, 2012).

The challenges in collaborative governance practices stem from the structural complexity of the government units being managed. There are six aspects of complexity, namely: employment relations, institutional membership, 
work and management structures, pluralism, ambiguity, and dynamics. Collaborative advantage depends on the diversity of members. Potential comes from how to take advantage of differences and create possible synergies. This diversity dimension consists of dimensions of resources and goals, dimensions of language and culture, and dimensions of power (Huxham, et.al., 2000).

The Indonesian government uses two different terms related to military and non-military relations. The first term is non-militer (non-military), which refers to a set of issues other than military issues, and embedded with the concept of threats, becoming a non-military threat. The second term is nir-militer (also translated as "nonmilitary"), which refers to an institutional framework outside the military, in other words, a civilian organization, and is embedded in the concept of defense. However, in practice, the two are sometimes interchanged.

The Ministry of Defense of the Republic of Indonesia describes some of the non-military threats: climate change, disasters, food and clean water crises, epidemics, ideological threats, economic crises, the proliferation and use of certain technologies, and threats to the socio-cultural order (Ministry of Defense, 2015). The same thing was reaffirmed by the minister of defense for the 2014-2019 period, Ryamizard Ryacudu, emphasized that there were eight non-military threats to Indonesia: natural disasters, epidemics, border violations, separatism, cyber-attacks, drugs, terrorism, and cultural infiltration (Marboen, 2015). In reality, a threat entity has both military and nonmilitary features which are then accommodated in the Indonesian defense framework as a hybrid threat concept. Meanwhile, the Ministry of Defense describes the relationship between the military and non-military related to differences in the priority of the implementers in responding to the two types of military and non-military threats.

\section{Methodology}

This paper is a descriptive research by elaborating on the reality and theory of non-military defense and the theory of collaborative governance. Data collection is a literature study with the main sources are journal articles, books, statutory documents, or other forms of government regulation and news articles or press releases from credible sources.

\section{Result and Discussion}

\subsection{Pertahanan nirmiliter (non-military defense)}

Defense development in Indonesia, as mandated by Law No. 3 of 2002 aims to protect the country's sovereignty and territorial integrity as well as the safety of the nation. Therefore, by looking at the complexity of these defense objectives, the solution does not only rest on the Ministry of Defense but also becomes the responsibility of all related agencies, both government and non-government agencies. This function is carried out by elements of national power which consist of several elements: military and non-military forces which include ideological power, domestic politics and diplomacy, economy and finance, socio-culture, technology, psychology, information, geography, demography, and natural resources.

Non-military defense is the mandate of Law No. 3 of 2002 on national defense. Article 7 paragraph 2 states that the state defense system faces non-military threats placing ministries / institutions outside the defense sector as the main element in accordance with the form and nature of the threats faced supported by other elements of the nation's power by utilizing regional governments. To build non-military defense, the Ministry of Defense has developed a Strategy of Non-Military Defense Guidelines (Pedoman Strategi Pertahanan Nirmiliter) set by Defense Minister Regulation No. 19/2016. These guidelines are non-military defense implementation guidelines, so it needs to be understood by the ministries / institutions outside the field of defense and regional governments as well as other elements of national power.

Non-military Defense is prepared to face non-military threats and as a supporting force in facing military threats, so that this non-military defense system in its doctrine is called Dwi Bhakti Eka Dharma. Love for the homeland, awareness of state defense, and professionalism of human resources in Ministries / Institutions are imperative in playing themselves as the main elements of the nation's strength in facing non-military threats. Non-military threats are handled using a non-military approach, while the military defense functions in certain conditions as an element of assistance whose involvement is based on state policies and political decisions.

Regulation of the Minister of Defense of the Republic of Indonesia Number 26 of 2014 concerning National Defense Strategy describes that non-military defense resources are based on the participation of Ministries / Agencies outside the defense sector as the Main Element (Unsur Utama) assisted by other elements of the nation's power in dealing with non-military threats. In developing non-military defense resources, civic education is 
manifested in Spirit of Defending Nation (Bela Negara). Forms of non-military threats include threats with ideological, political, economic, socio-cultural dimensions, information technology, threats with a public safety dimension. The involvement of citizens in non-military defense is adjusted to their profession, knowledge, and expertise in the Ministry / Institution by empowering national resources to support the implementation of national defense. The integration of non-military defense is carried out in two forms of service proportionally, namely between service to the profession and service to the interests of national defense.

Ministries/Institutions are non-military defense forces which in their roles, duties, and authorities manage and develop non-military defense resources that are managed, fostered, and utilized to ensure the success of national development sustainably in order to fulfill the interests of welfare. Synergistically, these resources must also be utilized to support the interests of national defense in facing non-military defense threats, and also be played as a supporting force in facing military threats.

The non-military defense is organized following the form and nature of the threat being faced. During times of peace, the implementation of non-military defense is carried out to create public welfare that can be used as a national force during wartime. The non-military defense is a force within a deterrence framework that is built and developed to achieve national security standards in the fields of ideology, politics, economics, socio-culture, psychology, and technology. Empowerment and utilization of Military Defense and Non-Military Defense in peacetime, apart from the purpose of deterrence, is also directed at providing a stability effect that enables national development to be carried out to achieve a better level of people's welfare.

Furthermore, in Permenhan Number 26 of 2014, it is explained that during the war period, non-military defense was carried out by mobilizing the strength and ability of the community as well as all National Resources in supporting efforts to win the war. Diplomacy efforts are based on the role of non-military defense carried out through political and economic approaches. At the same time, other military and non-military defenses were deployed to strengthen diplomacy efforts, as well as to carry out further stages if diplomacy was deadlocked.

An active defensive strategy in dealing with non-military threats is carried out by ministries/institutions outside the defense sector by preparing regional potentials to become defense forces. The process of preparing the state's territory as a defense field is carried out in an integrated and coordinated manner, between institutions and agencies, which is realized through the arrangement of the defense space area. In addition to this, ministries/agencies prepare defense logistics early and integrated with national development for welfare purposes.

Non-military defense is related to its function as the main element which is essentially the defense of individual security. Individual security shifts the main object of analysis to the human level as popularized by the Welsh school and human security perspective (Hama, 2017). This terminology does not deny the existence of the state in calculating security but rather adjusts the pattern of interaction between individuals and the state by placing individuals as ends and the state as the means. The state even remains the main actor that creates a sense of security for each individual or community group as described (Sorensen, 1996). Thus, the measure of the success of governance in non-military defense is the maximization of the fulfillment of fundamental rights and the development of citizens.

\subsection{Collaborative Governance of Non-Military Defence}

The collaborative government can and has been widely applied at various scales of government from the highest to the lowest, such as for rural development affairs (Febrian, 2016). China has become a new global power, one of which is by implementing a collaborative government when it comes to dealing with extraordinary national challenges (poverty, HIV, etc.) amid its very fast-growing economy. China mobilizes its citizens, non-profit organizations, private firms and other actors in managing local community service issues, national disaster insurance, social services and sustainable development (Brown, Gong, and Jing, 2012).

What China has practiced above is a very relevant example in building national resilience or defense in the nonmilitary sector. Amid situations of conflicting ideologies, capabilities and asymmetrical interests between parties, the proliferation of non-military threats has become the most threatening for many (Thornton, 2007). This situation seems to have been realized by the Ministry of Defense, which several years ago declared military defense a national program. The Directorate General of Defense Potential, said that all ministries/agencies must carry out this to deal with the complexity of non-military threats (Hakim, 2015).

Collaborative governance requires the existence of organizations and mechanisms that cover collaboration between parties on an issue. Permenhan number 26 of 2014 explains that non-military defense requires an institution that can coordinate the role of Ministries/Institutions to deal with non-military threats. 
Ministries/agencies outside the defense sector need to acknowledge the threat from non-military aspects whose handling requires synergy with other elements of the nation's strength. The absence of institutional synergy means that in a condition of facing contingent non-military threats, there is a risk of failure to implement the national defense strategy.

Synergy, a fundamental element in collaboration, is the main key in carrying out the non-military defense function. In contrast to military defense which is carried out by only one institution, non-military defense is very complex because it covers all ministries and civilian institutions which have very different fields of work, mechanisms, and organizational cultures. Non-military defense requires the support of shared perceptions. In non-military defense, apart from having to synergize with military defense forces, it is necessary to have a common perception among the Ministries / Agencies concerned regarding the duties, obligations, and roles of each in the implementation of national defense. Similar perceptions are also needed to build and maintain synergy between military and nonmilitary defense forces.

Criticism and difficulties in dealing with non-military threats are often caused by a lack of or weak collaboration in the defense structure of a country. One form of non-military threat that is spreading today, the spread of disease outbreaks, has historically proven that there is a great dependence on the success of epidemic management on collaborative governance. Disregard for professional input for the sake of political urgency, the bureaucracy that is overwhelmed to complete any handling work amid the complexity of the impact of the epidemic, and the actions of a group of people in the community who act contradictory are the main causes of problems in implementing defense against the epidemic (LeMay, 2016, pp. 77-90)

Chart 1. The Complexity of Collaborative Governance Within Non-Military Defence

\begin{tabular}{|c|c|c|}
\hline Role collaboration & Issue collaboration & Actor collaboration \\
\hline $\begin{array}{l}\text { Unsur utama (main } \\
\text { elements) face non- } \\
\text { military threats } \\
\text { Unsur pendukung } \\
\text { (supporting elements) } \\
\text { face military threats }\end{array}$ & $\begin{array}{l}\text { Ideology } \\
\text { Politic } \\
\text { Economic } \\
\text { Social } \\
\text { Cultural } \\
\text { Environment } \\
\text { Public Safety }\end{array}$ & $\begin{array}{l}\text { Ministries } \\
\text { State Agencies } \\
\text { Civil organizations } \\
\text { Another civilian entity }\end{array}$ \\
\hline
\end{tabular}

The Ministry of Defense has compiled a Strategic Non-military Defense Guideline which is stipulated by the Minister of Defense Regulation Number 19 of 2016. These guidelines are guidelines for the implementation of non-military defense. Thus, Ministries / Institutions and local governments as well as other elements of national power have a vision of national defense and can accommodate national defense policies as a basis for managing and fostering according to their respective sectors to build an efficient non-military defense force.

In accordance with the concept of the stages of collaborative government implementation described in the previous chapter, implementation of non-military defense forces can also be applied in four phases: study, initiation, negotiation, and implementation. In the first stage, there needs to be an analysis of the strategic security environment from global to local levels and an inventory of all non-military threats. The parties that will collaborate, namely the relevant ministries and agencies were also identified. In the second stage, the initiation begins with the involvement of all related parties, including the community, to design a non-military defense strengthening process while strengthening community resilience. This kind of strengthening of social capital correlates with the reality that the community is "first aid" in deterring non-military threats. 
Chart 2. Implementation of collaborative governance in non-military defense

\begin{tabular}{|c|c|c|c|}
\hline $\begin{array}{l}\text { Analyzing non- } \\
\text { military defence } \\
\text { Strategic } \\
\text { environment } \\
\text { analysis } \\
\text { identify relevant } \\
\text { ministries and } \\
\text { agencies } \\
\text { Strategic plan }\end{array}$ & 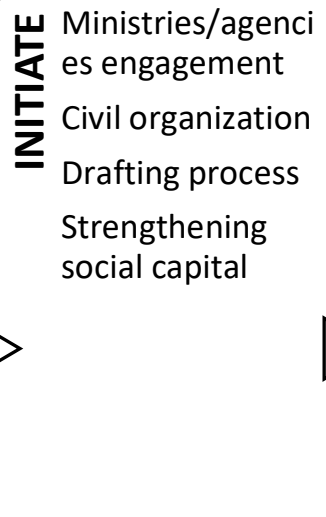 & $\begin{array}{l}\text { Facilitating } \\
\text { consultation } \\
\mathbf{E} \text { among parties } \\
\mathbf{Z} \text { negotiation of } \\
\text { interest } \\
\text { creating work } \\
\text { team } \\
\text { formulating lega } \\
\text { basis }\end{array}$ & $\begin{array}{l}\text { 岳 developing work } \\
\text { plan } \\
\text { 岂 } \\
\text { designing } \\
\text { management } \\
\text { structure } \\
\text { managing } \\
\text { working network } \\
\text { conflict resolution } \\
\text { evaluating the } \\
\text { performance of } \\
\text { non-military } \\
\text { defence }\end{array}$ \\
\hline
\end{tabular}

The third stage is to negotiate the legal foundation for strengthening non-military defense, which is no longer at the boundaries of the manual and then forming work units after trying to accommodate the interests of each party. In the next stage, implementation begins by developing a pre-arranged plan, managing networks, resolving internal and external disputes, and continuing to evaluate its achievements.

\section{The challenges on the implementation of collaborative governance within non-military defense}

Collaborative implementation is not without challenges. Two things that are common in this method of public affairs governance are the imbalance of power and incomplete legal foundations. These two factors are related to each other and have a significant effect on the way the collaboration works. Asymmetrical power between parties makes collaborative governance processes vulnerable to manipulation by stronger participants or even less participation from stakeholders who should be involved more (Huiting Qi, 2019). The easiest example to find is the handling of the threat of environmental damage. Customary groups, small communities, and environmentalists often lose when battling the powerful plantation companies or mining companies because of their alignments of bureaucratic forces.

The second challenge is to strengthen the role of law in overcoming negative impacts that arise as a result of the unequal distribution of power in collaborative governance. The legal foundation also plays a role in promoting stakeholder representation and different aspirations to unite in one collaboration. In the context of non-military defense, the legal basis is not yet as established as military defense and has not been able to accommodate crosssectoral defense collaboration. Military defense apart from being supported by Law Number 34 of 2004 concerning the Indonesian National Army (TNI) is also strengthened by law number 23 of 2019 concerning the management of national resources which clearly outlines the mechanisms and duties of each component, both the main components, reserves componenet, supporting component, and national infrastructure.

Issues that will be faced and of course must be followed up so that the collaborative approach can be applied effectively and can be categorized into three efforts: (1) solving substantive problems; (2) the collaboration process; and (3) cross-party accountability (Waardenburg, et.al, 2020, p. 390). The substantive problem in non-military defense is the non-military and internal threats to the non-military component itself. The collaborative process is related to the synergy between civilian organizations and the synergy between civilians and military. This synergy is of course followed by professionalism and mutual trust because the flow of orders and mechanisms built on non-military defense is dominated by collaboration, not hierarchy. Furthermore, accountability is related to the responsible commitment of each party in the non-military defense building.

The implementation of the collaborative government model in Indonesia is not easy because it requires holistic government collaboration between the government and non-government sectors. A simple case study is that tourism development in the Buton region is ineffective due to a lack of collaboration between the local government and the private sector (Islamy, 2018). The commitment to collaborate and eradicate sectoral egos is, of course, the main mission when any collaborative government will be enforced, including when applied to Indonesia's nonmilitary defense framework.

The collaborative government will indeed produce so many alternatives to an issue because there are more actors 
involved. However, this is the best step to get brilliant input and trigger better participation in quality and quantity from the community. Moreover, non-military issues are issues that exist and are felt in the midst of the daily life of society, not those that are limited to circulating on cabinet meeting tables or blackboards at military headquarters. The dominance of one's rationality and perception of handling an issue tends to result in decisions that are less favorable and often disappointing (Doberstein, 2016, p. 5).

Chart 3. The must-addressed challenges in strengthening non-military defense by implementing collaborative governance. Source: Waardenburg, Groenleer, de Jong, Keijser (2020)

\begin{tabular}{ll}
\hline \multicolumn{1}{c}{ Category } & \multicolumn{1}{c}{ Issue } \\
\hline $\begin{array}{l}\text { Substantive problem } \\
\text { solving }\end{array}$ & $\begin{array}{l}\text { Identify and define the non-military threats in both local and international } \\
\text { strategic environment. Included in this context, mechanisms on encountering } \\
\text { hybrid threats. }\end{array}$ \\
\cline { 2 - 2 } Collaborative process & $\begin{array}{l}\text { Develop performance and successful threat handling indicators } \\
\text { Have a common understanding of the aims and approaches used in building } \\
\text { and strengthening non-military defense }\end{array}$ \\
\cline { 2 - 2 } $\begin{array}{l}\text { Build mutual trust between ministries and institutions, as well as between } \\
\text { civilians and the military }\end{array}$ \\
\cline { 2 - 2 } $\begin{array}{l}\text { Ensuring the commitment of each party is not limited to discourse } \\
\text { accountability }\end{array}$ & $\begin{array}{l}\text { Maintaining the harmony of central and regional work as well as relations } \\
\text { between branches of government (executive, legislative, judiciary) }\end{array}$ \\
\cline { 2 - 2 } & $\begin{array}{l}\text { Maintaining accountability in non-military defense strengthening partnerships } \\
\text { with various elements of society }\end{array}$ \\
\hline
\end{tabular}

\section{Conclusion}

Collaborative governance is the most relevant answer to the multi-issue, multi-stakeholder, multi-cultural nature of non-military defense itself, and is prone to uncertainty, rapid change, and ambiguity. In contrast to the military tradition which is highly hierarchical and adopts an authoritarian command system, the non-military realm of defense can only develop and be implemented with an all-embracing and democratic approach. Moreover, while military defense is dealing with physical threats, the handling of which is clearly physical as well, in contrast to non-military defense dealing with non-physical threats, of course, the handling is faced with multi-power which involves many aspects according to one's profession and expertise. So it requires synergy that underlies the formallegal implementation in the form of collaborative government.

To follow up on the urgency of implementing a collaborative government approach in building non-military defense forces, it is necessary to strengthen the legal and institutional foundations that underlie Ministries/Agencies in planning and considering joint training efforts in emergency handling in order to build preparedness for non-military threats. The non-military defense law also needs to be realized as an implementation in the field. Besides that, the existing main non-military defense doctrine requires a derivative in the form of an implementing doctrine as a basic guideline for ministries/institutions in carrying out field collaboration with other elements of national power.

\section{References}

Brown, T., Gong, T., Jing, Y. (2012). Collaborative Governance in Mainland China and Hong Kong: Introductory Essay. International Public Management Journal, 15(4), pp. 393-404. DOI: 10.1080/10967494.2012.761048

Buzan, B., Wæver, O., \& Wilde, J. de. (1998). Security: A New Framework for Analysis. Boulder: Lynne Rienner Publishers, Inc.

Chris Huxham, S. Vangen, C. Huxham \& C. Eden (2000) The Challenge of Collaborative Governance, Public Management: An International Journal of Research and Theory, 2:3, 337-358, DOI: 10.1080/14719030000000021

Doberstein, C. (2016) Designing Collaborative Governance Decision-Making in Search of a 'Collaborative 
Advantage', Public Management Review, 18:6, 819-841, DOI: 10.1080/14719037.2015.1045019

Febrian, R. (2016). Collaborative Governance Dalam Pembangunan Kawasan Perdesaan. Wedana, 2(1), pp. 200-208

Hakim, S. (2015). Kemhan dorong pertahanan nirmiliter jadi program nasional. Retrieved July 11, 2020, from Antara News: https://www.antaranews.com/berita/860413/kemhan-dorong-pertahanan-nirmiliter-jadi-program$\underline{\text { nasional }}$

Hama, H. H. (2017). State Security, Societal Security, and Human Security. Jadavpur Journal of International Relations, 21(1), 1-19. https://doi.org/10.1177/0973598417706591

Huiting Qi. (2019). Strengthening the rule of law in collaborative governance, Journal of Chinese Governance, 4:1, 52-70, DOI: $10.1080 / 23812346.2019 .1565852$

Islamy, L. (2018). Collaborative Governance: Konsep dan Aplikasi. Yogyakarta: Deepublish

Johnston, E., D. Hicks, N. Nan, and J. C. Auer. 2011. "Managing the Inclusion Process in Collaborative Governance.” Journal of Public Administration Research and Theory 21 (4): 699-721. doi:10.1093/jopart/muq045.

Jokowi Potong Anggaran Kementerian/ Lembaga demi Covid-19, Berikut Rinciannya. (2020). Kompas.com. Retrieved from: https:/nasional.kompas.com/read/2020/04/13/06460991/jokowi-potong-anggaran-kementerianlembaga-demi-covid-19-berikut-rinciannya?page=all

Kementerian Pertahanan Republik Indonesia. (2015). Buku Putih Pertahanan Indonesia. Jakarta

Kementerian Pertahanan Republik Indonesia. (2017). Pedoman Strategis Pertahanan Nirmiliter. Jakarta

LeMay, M. C. (2016). Global Pandemic Threats: A Reference Handbook. Santa Barbara: ABC-CLIO.LLC.

Marboen, A. (2015) Delapan ancaman negara nirmiliter menurut Menteri Pertahanan. Retrieved July 11, 2020, from Antara News: https:/www.antaranews.com/berita/523063/delapan-ancaman-negara-nirmiliter-menurutmenteri-pertahanan

Morse, R. \& Stephens, J. (2012) Teaching Collaborative Governance: Phases, Competencies, and Case-Based Learning, Journal of Public Affairs Education, 18:3, 565-583, DOI: 10.1080/15236803.2012.12001700

Oktaviano, D., Mahroza, J., Risman, H., (2020). Indonesia Defense Strategy Towards Indo-Pacific (Case Study: The ASEAN Outlook on the Indo-Pacific). International Affairs and Global Strategy, 80, 21-29, DOI: 10.7176/IAGS/80-04

O’Leary Rosemary, Beth Gazley, Michael McGuire, and Lisa Blomgern Bingham, 2008, Public Managers in Collaboration in The Collaborative Public Manager; New Ideas for the twenty-firs century, ed Rosemary O'Leary and Lisa Blomgern Bingham, Washinton DC; Georgetown University Press.

Peraturan Menteri Pertahanan Republik Indonesia Nomor 26 Tahun 2014 Tentang Strategi Pertahanan Negara

Sørensen, G. (1996). Individual security and national security: The state remains the principal problem. Security Dialogue, 27(4), 371-386. https://doi.org/10.1177/0967010696027004002

Thornton, R. (2007). Asymmetric Warfare. Cambridge: Polity Press.

Undang-Undang Republik Indonesia Nomor 3 Tahun 2002 tentang Pertahanan Negara

Undang-Undang Republik Indonesia Nomor 23 Tahun 2019 tentang Pengelolaan Sumber Daya Nasional Untuk Pertahanan Negara

Wargadinata, E. (2017). Kepemimpinan Kolaboratif. Jurnal Administrasi Pemerintahan Daerah, 8(1), p. 1-14

Waardenburg, M., Martijn Groenleer, Jorrit de Jong \& Bas Keijser (2020) Paradoxes of collaborative governance: investigating the real-life dynamics of multi-agency collaborations using a quasi-experimental action-research approach, Public Management Review, 22:3, 386-407, DOI: 10.1080/14719037.2019.1599056 